\title{
Economist e-Readiness Rankings Show Uneven Progress
}

The Economist Intelligence Unit (EIU) in a press release reporting its 2008 e-Readiness Rankings, identified three key developments:

- The US is now top of the table, followed closely by Hong Kong.

- Digital progress slows in Denmark and other European ICT leaders.

- The digital divide between the top and lower tiers continues to narrow, but more slowly.

"E-readiness continues to advance across the globe. Indeed, the average e-readiness score of the 70 countries in this year's rankings rose to 6.39 (on a 1-10 scale), up from 6.24 in 2007. This overall progress, however, masks some backtracking among a handful of countries, notably within the top ten. After four consecutive years as the world's most e-ready country, Denmark has fallen four places, as has Switzerland. Similarly, Finland has dropped three places and has been supplanted in the top 10 by Austria. The United States is now the global e-readiness leader, with a score of 8.95 , followed closely by Hong Kong, which has advanced two places.

"Maintaining the momentum of digital development is clearly quite tough. The aforementioned European ICT leaders have been unable, in some areas, to sustain the heady pace of development they had previously established. Both Finland and Denmark, for instance, were unable to maintain previous ICT spending levels or to improve upon (albeit impressive) public and corporate access to digital channels. By contrast, those countries that have advanced in the top 10 - the US, Hong Kong, the Netherlands and Australia - have largely done so on the back of improvements in connectivity - both in fixed and wireless broadband access, as well as in their innovation environments.
"The world's most developed digital economies and many less developed ones - continue to record impressive gains in broadening access to ICT and making digital services available to the population," says Robin Bew, Editorial Director of the Economist Intelligence Unit. "It is hard work to maintain this progress, however, and even the leaders have much to do to translate these gains into real economic and social benefits".

"The gap between the "haves" and "have-nots" in our rankings narrowed again in 2008, a hopeful indication of a contraction in the digital divide between developed and developing countries. However, the narrowing of this gap was considerably less than in previous years. The least e-ready countries have registered no upward movement in their rankings (although most have improved their scores), partly because their business environments have deteriorated or improved only slightly. Connectivity improvements in some developing countries, particularly in Latin America, are also alarmingly slow. Other lower ranked countries, however, such as Saudi Arabia, Thailand and Egypt, have moved upwards thanks mainly to faster progress in connectivity.

"In our research we have identified three tiers of countries within the e-readiness rankings: established leaders, rapid adopters and late entrants," says Peter Korsten, Global Leader of the IBM Institute for Business Value. "These groups have remained relatively constant, but the most impressive improvements have been registered by the 'late entrants', as exemplified by countries such as Thailand, Peru, and Romania, which have risen in the rankings by up to 17 places between 2001 and 2008."

"Since 2000, the Economist Intelligence Unit has published an annual e-readiness ranking of the world's largest economies, using a model developed in co- 
operation with the IBM Institute for Business Value. A country's "e-readiness" is a measure of its e-business environment, a collection of factors that indicate how amenable a market is to Internet-based opportunities. Increasingly, it is also about how individuals and businesses consume digital goods and services.

"Our analysis in 2008 identifies several guiding principles that policymakers can use to evaluate the opportunities for advancing e-readiness in their countries:

\begin{tabular}{|c|c|c|c|c|}
\hline $\begin{array}{c}2008 \text { e- } \\
\text { readiness } \\
\text { rank (of 70) }\end{array}$ & $\begin{array}{l}2007 \\
\text { rank }\end{array}$ & Country & $\begin{array}{c}2008 \text { e- } \\
\text { readiness } \\
\text { score (of } 10 \text { ) }\end{array}$ & $\begin{array}{l}2007 \\
\text { score }\end{array}$ \\
\hline 1 & 2 & United States & 8.95 & 8.85 \\
\hline 2 & 4 & Hong Kong & 8.91 & 8.72 \\
\hline 3 & 3 & Sweden & 8.85 & 8.85 \\
\hline 4 & 9 & Australia & 8.83 & 8.46 \\
\hline 5 & 1 & Denmark & 8.83 & 8.88 \\
\hline 6 & 6 & Singapore & 8.74 & 8.60 \\
\hline 7 & 8 & Netherlands & 8.74 & 8.50 \\
\hline 8 & 7 & United Kingdom & 8.68 & 8.59 \\
\hline 9 & 5 & Switzerland & 8.67 & 8.61 \\
\hline 10 & 11 & Austria & 8.63 & 8.39 \\
\hline 11 & 12 & Norway & 8.60 & 8.35 \\
\hline 12 & 13 & Canada & 8.49 & 8.30 \\
\hline 13 & 10 & Finland & 8.42 & 8.43 \\
\hline 14 & 19 & Germany & 8.39 & 8.00 \\
\hline 15 & 16 & South Korea & 8.34 & 8.08 \\
\hline 16 & 14 & New Zealand & 8.28 & 8.19 \\
\hline 17 & 15 & Bermuda & 8.22 & 8.15 \\
\hline 18 & 18 & Japan & 8.08 & 8.01 \\
\hline 19 & 17 & Taiwan & 8.05 & 8.05 \\
\hline 20 & 20 & Belgium & 8.04 & 7.90 \\
\hline 21 & 21 & Ireland & 8.03 & 7.86 \\
\hline 22 & 22 & France & 7.92 & 7.77 \\
\hline 23 & 24 & Malta & 7.78 & 7.56 \\
\hline 24 & 23 & Israel & 7.61 & 7.58 \\
\hline 25 & 25 & Italy & 7.55 & 7.45 \\
\hline 26 & 26 & Spain & 7.46 & 7.29 \\
\hline 27 & 27 & Portugal & 7.38 & 7.14 \\
\hline 28 & 28 & Estonia & 7.10 & 6.84 \\
\hline 29 & 29 & Slovenia & 6.93 & 6.66 \\
\hline 30 & 32 & Greece & 6.72 & 6.31 \\
\hline 31 & 31 & Czech Republic & 6.68 & 6.32 \\
\hline 32 & 30 & Chile & 6.57 & 6.47 \\
\hline 33 & 34 & Hungary & 6.30 & 6.16 \\
\hline 34 & 36 & Malaysia & 6.16 & 5.97 \\
\hline 35 & 33 & United Arab Emirates & 6.09 & 6.22 \\
\hline 36 & 39 & Slovakia & 6.06 & 5.84 \\
\hline 37 & 37 & Latvia & 6.03 & 5.88 \\
\hline 38 & 41 & Lithuania & 6.03 & 5.78 \\
\hline 39 & 35 & South Africa & 5.95 & 6.10 \\
\hline 40 & 38 & Mexico & 5.88 & 5.86 \\
\hline 41 & 40 & Poland & 5.83 & 5.80 \\
\hline 42 & 43 & Brazil & 5.65 & 5.45 \\
\hline 43 & 42 & Turkey & 5.64 & 5.61 \\
\hline 44 & 44 & Argentina & 5.56 & 5.40 \\
\hline 45 & 45 & Romania & 5.46 & 5.32 \\
\hline 46 & 47 & Saudi Arabia & 5.23 & 5.05 \\
\hline
\end{tabular}

\begin{tabular}{cclcc}
\hline $\begin{array}{c}2008 \text { e- } \\
\text { readiness } \\
\text { rank (of 70) }\end{array}$ & $\begin{array}{c}2007 \\
\text { rank }\end{array}$ & Country & $\begin{array}{c}2008 \text { e- } \\
\text { readiness } \\
\text { score (of 10) }\end{array}$ & $\begin{array}{c}2007 \\
\text { score }\end{array}$ \\
\hline 47 & 49 & Thailand & 5.22 & 4.91 \\
48 & 48 & Bulgaria & 5.19 & 5.01 \\
49 & 46 & Jamaica & 5.17 & 5.05 \\
50 & - & Trinidad \& Tobago* & 5.07 & - \\
51 & 51 & Peru & 5.07 & 4.83 \\
52 & 50 & Venezuela & 5.06 & 4.89 \\
53 & 52 & Jordan & 5.03 & 4.77 \\
54 & 54 & India & 4.96 & 4.66 \\
55 & 55 & Philippines & 4.90 & 4.66 \\
56 & 56 & China & 4.85 & 4.43 \\
57 & 58 & Egypt & 4.81 & 4.26 \\
58 & 53 & Colombia & 4.71 & 4.69 \\
59 & 57 & Russia & 4.42 & 4.27 \\
60 & 61 & Sri Lanka & 4.35 & 3.93 \\
61 & 60 & Ukraine & 4.31 & 4.02 \\
62 & 62 & Nigeria & 4.25 & 3.92 \\
63 & 59 & Ecuador & 4.17 & 4.12 \\
64 & 63 & Pakistan & 4.10 & 3.79 \\
65 & 65 & Vietnam & 4.03 & 3.73 \\
66 & 64 & Kazakhstan & 3.89 & 3.78 \\
67 & 66 & Algeria & 3.61 & 3.63 \\
68 & 67 & Indonesia & 3.59 & 3.39 \\
69 & 68 & Azerbaijan & 3.29 & 3.26 \\
70 & 69 & Iran & 3.18 & 3.08 \\
\hline
\end{tabular}

* New to the annual rankings in 2008.

Note: A four-decimal score is used to determine each country's rank. Source: Economist Intelligence Unit, 2008.

- Let the market build it. Competitive telecoms and Internet service markets are more efficient than governments in building networks and finding affordable price points for consumers. Policymakers should allow market forces to determine the course of the digital economy, and must resist the urge to steer its ICT industry into technology-specific directions.

- But step in when needed. Governments must, at the same time, ensure that investment finds its way to society's digital "have-nots"; rural and poor communities, for example, tend to be left behind if service providers follow a purely market-driven course.

- Lead by example. In poorer countries, governments should strive to be an early adopter of digital practices that other organisations and individuals can emulate. They can also create demand for technology and digitally enabled services, both through their own direct purchases and through the creation of additional channels for procurement, tax filing and other operations.

- Don't do it all. Governments must champion digital development, fund their own ICT infrastructure, regulate lightly and encourage others to adopt - a complex juggling act. But they must also be 
as unobtrusive as possible if digital business is to thrive. For one thing, they should remain staunchly technology-neutral in their procurement and licensing practices.

- Keep at it. As this year's rankings show, it is precariously easy to fall back on more strategic digital objectives, and thus lose some of the ground gained in building networks and communities. The world of e-readiness is a place with ever-shifting targets, where policy and practices must be reviewed and refreshed frequently in order to meet the aspirations of the communities that governments serve.

E-readiness rankings 2008: Maintaining momentum is available free of charge at www.eiu.com/sponsor/ibm/ e-readinessrankings 2008

\section{Methodology: How the scores were derived}

Nearly 100 quantitative and qualitative criteria, or- ganized into six distinct categories, feed into the ereadiness rankings. The six categories (and their weight in the model) are connectivity and technology infrastructure (20\%); business environment (15\%; the nine criteria used here summarize the 70 indicators covered by the Economist Intelligence Unit's business environment rankings); social and cultural environment (15\%); legal and policy environment $(10 \%)$; government policy and vision (15\%); and consumer and business adoption $(25 \%)$.

The data used in the rankings are sourced from the Economist Intelligence Unit, Pyramid Research, the World Bank, the World Intellectual Property Organization and others. Qualitative criteria are assessed by the Economist Intelligence Unit's extensive network of country experts, and their assessments are reviewed by our top economists. 